\title{
The milking potential of the local house-cow in the Republic of Yemen
}

\author{
R. G. Clemence ${ }^{1}$ and H. Salem Ahmed ${ }^{2}$ \\ ${ }^{1}$ Centre for Tropical Veterinary Medicine, Easter Bush, Roslin EH25 9RG \\ ${ }^{2}$ Central Highlands Rural Development Project, Risabah, Republic of Yemen
}

\section{Introduction}

The Yemen Arab Republic now part of the Republic of Yemen is a country of approximately $195000 \mathrm{~km}^{2}$ (proportionately 0.85 of the size of the UK), running down the eastern side of the Red Sea, with a population of $9 \times 10^{h}$ people, $85 \%$ of whom are considered rural. It is regarded as one of the 25 poorest countries in the world with high infant mortality and a life expectancy of 51 years.

The vast majority of farms in the Central Highland region (altitude 1500 to $3000 \mathrm{~m}$ above sea level) are small, 2 to 4 ha family-owned units devoted almost exclusively to cropping, with little or no grazing. On such units livestock keeping, although common, is very much a secondary activity, with the exception of milk production from the house-cow. Such animals are important status symbols and their milk is an essential part of the farming family's daily diet.

Under traditional management these shorthorned small zebu ( $B$ os indicus) -type animals produce between 550 and $700 \mathrm{~kg}$ milk per lactation. The average calving interval is between 395 and 457 days. A basal diet of sorghum stover supplemented with alfalfa and/or household scraps, is hand fed by the women of the household, which takes up to 5 to $6 \mathrm{~h} /$ day.

\section{Material and methods}

A trial was conducted to investigate the milking potential of such animals under appropriate improved feeding and management. Seven randomly selected heifers, kept in individual pens, were given a basal diet of sorghum stover ad libitum, supplemented with fresh alfalfa, crushed wheat and a concentrate $(10 \mathrm{MJ}$ metabolizable energy and $220 \mathrm{~g}$ crude protein per $\mathrm{kg}$ dry matter (DM)), manufactured on-site, from local ingredients. Prior to calving, each animal received $2 \mathrm{~kg}$ alfalfa, $1 \mathrm{~kg}$ crushed wheat and $1 \mathrm{~kg}$ concentrate daily. After calving, concentrate and alfalfa allowances were each increased by $0.5 \mathrm{~kg} /$ day. Stover intakes throughout the trial were 5 to $6 \mathrm{~kg}$ DM per day. Cows were machine milked twice a day.

\section{Results}

The mean first lactation milk yield of the seven cows was 1377 (s.e. 130.9, range 826 to 1825 ) $\mathrm{kg}$, over a mean lactation of 273 (s.e. 17.5 , range 172 to 313 ) days. This was considerably higher than yields under traditional management. The cost of the concentrate supplement per $\mathrm{kg}$ of extra milk produced (over the traditional systems) was calculated to be 4.3 Yemeni rials per $\mathrm{kg}$ milk (at 1990 prices). This compared favourably with the retail value of milk in the towns of 15 Yemeni rials per kg. The majority of farmers in the highlands could afford to purchase the concentrates. On a metabolic weight basis, the annual milk yield of the best cows $(32.7 \mathrm{~kg}$ milk per $\mathrm{kg}$ live weight $\mathrm{t}^{0.75}$ ) compared favourably with an average Friesian heifer in Europe $(37.1 \mathrm{~kg}$ of milk per $\mathrm{kg}$ live weight ${ }^{0.75}$ ).

\section{Discussion}

The results indicate that there is considerable potential for increasing milk production in Yemen from the existing indigenous animals through simple improvements in husbandry and nutrition. This coupled with a selective breeding policy to exploit the genetic potential within the local stock could dramatically improve the productivity of the housecow.

\section{Acknowledgement}

This trial was carried out under the auspices of the Central Highland Rural Development Project, a project jointly funded by the Overseas Development Administration, UK, the World Bank and the Government of the Republic of Yemen. 